\title{
Introduction:New perspectives on China - Central and Eastern Europe relations
}

\author{
Anastas Vangeli ${ }^{1} \cdot$ Dragan Pavlićević $^{2}$ \\ Published online: 5 October 2019 \\ (C) Springer-Verlag GmbH Germany, part of Springer Nature 2019
}

China's relations with Central and Eastern Europe (CEE) have been progressively attracting attention in recent years. In the last decade, China sought to restore the "bridges" (Wasserstrom 2000) with the region that had existed in the period 1949-1989. Chinese policymakers have long contemplated their "return" to CEE (Tubilewicz 1998); however, they have found the right opportunity only in the period after the global financial crisis. The first trade and investment summit of China and the sixteen countries in the region-Albania, Bulgaria, Croatia, the Czech Republic, Estonia, Hungary, Latvia, Lithuania, Montenegro, (North) Macedonia, Poland, Romania, Serbia, Slovakia, and Slovenia-took place in Budapest in 2011. In 2012, the first summit of the heads of governments of China and the sixteen (collectively known as 16+1) took place in Warsaw. Ever since, these summits have been taking place once a year, while a web of coordinating institutions and mechanisms spanning a number of policy fields has been also established. There is now a whole new universe of interactions involving governmental actors on the national, regional/provincial, and local levels, state-owned and private enterprises, think tank(er)s, and media professionals, as well as other people-to-people exchanges, which now take place with growing frequency and contribute to development of China-CEE relations.

Consequently, China looms as large as never before in the outlook of the CEE countries and the China-CEE relationship appears set to continue developing and deepening into the future. In 2019, it was announced that the China-Central and Eastern Europe Cooperation framework, as this multilateral initiative is formally known, will be expanded with Greece joining as a full member. This illustrates the wide-ranging

Anastas Vangeli

avangeli@sns.edu.pl

Dragan Pavlićević

dragan.pavlicevic@xjtlu.edu.cn

1 Graduate School for Social Research, Institute of Philosophy and Sociology, Polish Academy of Sciences, Warsaw, Poland

2 Xi'an Jiaotong - Liverpool University, Suzhou, PR China 
impact of the initiative and introduces new dynamics to China's relationship not only with CEE but to wider Europe as well. ${ }^{1}$ Such re-emergence of China-CEE relations in the post-crisis era opens two main lines of inquiry that span various themes and disciplines, and concern (a) the driving forces behind and objectives of China's approach to CEE, and the place of the region and 16+1 within China's foreign policy; and (b) the implications of $16+1$ for CEE and beyond.

As one of the recently established China-led multilateral platforms with regional focus, closely following the template set with the Forum on China-Africa Cooperation, and later employed more widely with the establishment of Forum on Cooperation between China and the Pacific Islands and China and the Community of Latin American and Carribean Countries, 16+1 reflects China's wider strategy of setting up regional multilateral institutions. Furthermore, in recent years, 16+1 has been aligned with the Belt and Road Initiative (BRI). The sixteen countries have all signed MoUs on the BRI, increasing the region's significance for China's diplomacy. Hence, ChinaCEE relations provide a fertile ground for studying not only regional policies of China, but its evolution as a global power and the evolving context of its relationship with world.

Furthermore, 16+1 has added another layer to the rather complex relationship between China and Europe (and in a broader sense, between China and the West). China-CEE relations have been increasingly affecting not only China-Europe but also intra-European relations and debates. Europeans have historically struggled to speak struggled to speak with one voice on external relations, including on Europe's relations with China. 16+1 offers a litmus test for European's coherence and unity. So far, the varied reactions to $16+1$ and China's emergence as a regional actor in CEE suggest that not only do Europeans pursue different external policies based on different interests, but also that inside Europe there are different needs and ideas on development, that in turn shape their respective differences with regard to China.

The process of building up 16+1 and the context in which it is developing are no less rich in meaning, revealing not only the complexities of China's predicament as a latecomer in regional, and indeed global, politics, and governance, but also multiple layers and facets of engagement with the CEE. The selection of the sixteen original countries, all of which are post-socialist (and as of recently, the addition of Greece, which is an exception in this regard), of which 11 (with Greece, this number increases to 12) are members of the EU, and 14 (with Greece, 15) are NATO members, touches upon the question of not only the composition of the CEE region, but also the processes of region formation, its identity, and position in the global politics and economy. The policy measures that China promotes and the discourse it projects in CEE, in dialog with the emerging CEE discourse on China, also poses important questions about whose ideas, norms, values, and policy principles drive the relationship, to what ends, and with what consequences. $16+1$ is a Chinese-led endeavor, meaning that despite the rhetoric of equality, it is a framework for an asymmetrical interaction. At the same time, $16+1$ has been born and developed in an age when a

\footnotetext{
${ }^{1}$ The inclusion of Greece has raised questions about the naming of the initiative. At the time of the preparation of this special issue, the initiative has still been referred to as $16+1$, rather than $17+1$. Therefore, in this and the rest of the articles in the issue, authors use the reference $16+1$.
} 
number of political and economic principles and blueprints which were accepted as international "golden standards," together with the tenets of the overarching supranational organizational framework in Europe, are questioned - not least in the CEE region. Such context multiplies not only the number of variables that do or may affect China-CEE relationship(s), but also the possible shortand long-term outcomes and implications.

\section{State of the art}

Yet, despite such rich context, the $16+1$ and the related developments topic are still insufficiently examined in the Anglophone academic literature. Emerging, or rather reemerging, after decades of neglect (and almost non-existence in the academic literature), the study of China-CEE has naturally faced the predicament of having scarce foundations upon which researchers could build. Furthermore, China-CEE is a research area lacking ready-to-go expertise: most of the international relations scholars in China are relatively unfamiliar with CEE, and very few scholars in CEE are familiar with China; and there are almost none, in China, CEE, or elsewhere, whose interest and expertise span both sides of the equation. The sparsity of research in this area is therefore understandable; yet, more research is urgently needed if we are to gain a better, more nuanced, and more comprehensive understanding of China-CEE relations, their evolution over the recent years, and the impact of it all on national, regional, or broader international level.

In the early years of $16+1$, most of the research tried to make sense of the sudden development of China-CEE relations, with researchers predominantly discussing motivations and objectives behind China's engagement of the region and examining the economic and political foundations of the relationship. Simultaneously, much of the early scholarship on the CEE region tackled China-CEE relations from a policy perspective and/or was produced by think tanks in China, CEE, and increasingly Western Europe and the USA. Many authors tried to fit the topic of China-CEE relations into the particular national and regional debates, including the ones on the appropriate course of action respective national governments should take with regards to China. On one hand, Chinese scholars have evaluated the effectiveness of China's foreign policy toward the region and recommended measures that would improve it. On the other, CEE scholars have tried to interpret China's intentions and recommend a course of action, often falling into two camps: those who see China as an opportunity and thus offer policy proposals to maximize the national and regional benefits; and those who see China as a threat and thus make proposals on how to resist and constrain China (Pavlićević 2018; Grzywacz 2019).

Nevertheless, the nascent academic literature has provided valuable insights, setting solid foundation for further research endeavors. Fürst and Tesař (2013) contextualized China's "charm offensive" in CEE as enabled by the post-ideological and posttransitional approach driven by "material interest" on both sides. Researchers also investigated China-CEE relations in the context of the BRI and assessed perceptions of China and its diplomacy in the region (Vangeli 2017; Matura 2018; Pendrakowska 2018; Kavalski 2018). Others provided initial analysis of the trade and investment flows (Shang et al. 2016; McCaleb and Szunomár 2017). 
Research is now gradually moving beyond and diversifying away from the "basics" of China-CEE relations to explore new avenues. Authors have increasingly started to ask questions that are relevant for understanding the trajectories of both China and CEE in global politics, brought in new analytical levels of analysis, such as sub-regional and subnational, and introduced comparative perspectives. The edited volume by Song (2017) marked a first book-length academic effort to investigate China-CEE relations and to account for multiple vectors and dimensions of China-CEE relations. Jakóbowski (2018) and Kowalski (2017), as well as Song and Pavlićević (2019), analyzed 16+1 as a part of the emerging global infrastructure of China-led regional multilateral diplomacy. Vangeli (2018) has centered on $16+1$ to trace the contours of studying Global China as an actor that possesses and emanates symbolic power.

Others investigated sources and extent of China's influence in CEE, especially in the context of China's growing economic ties with the region. For example, while Pepermans (2018) argued that China uses economic and soft power to gain political influence, Matura (2019) examined the limited political impact of China's economic diplomacy in the region. Moreover, Pavlićević (2019) provided comparative analysis of China's and the EU's economic, political, security, and soft power-related resources to accumulate and exercise leverage over CEE.

Others narrowed their focus on particular aspects and cases of China-CEE exchanges and interactions. Kamiński (2019) focused on the case of the Lodz region in Poland, initiating sub-national level of analysis of China-CEE relationship. Turcsányi and Qiaoan (2019) argued there is a dissonance between the official Chinese rhetoric that instrumentalizes the socialist past, and the anti-communist sentiments in CEE. Grgić (2017), focusing on the much-publicized case of China-backed highway project in Montenegro, examined how China's infrastructure diplomacy interacts with the domestic political context in a CEE country.

There is still however ample potential for further advancing the research agenda on China-CEE relations. With a large body of the literature epistemologically positioning the inquiry of $16+1$ within the premises of assumed China's grand strategy and hence seeking to identify China's goals and CEE role within it, the existing research has so far failed to account for the domestic drivers of China's approach to the region. Glaringly missing from the existing literature are attempts to contextualize China's engagement of CEE in the structural imperatives related to its developmental model and experience and how incentives and challenges therein contribute to the formation and delivery of its foreign policy.

Such focus on strategic level also entailed emphasizing state-level rather than actorlevel analysis and treating China as a unitary actor, preventing researchers from examining the role and interactions of various actors and stakeholders in China's policy toward CEE. This particularly applies to China's economic relations with CEE, which have been exclusively associated with China's state policies and capabilities to implement them and have neglected to account for a variety of rationalities guiding various bureaucratic and corporate actors. In line with such a state-centric approach, microlevel analysis, with some exceptions, focusing on particular areas and mechanisms of interaction has also been so far largely absent from the analysis.

Furthermore, there is ample space left for digging deeper into the soft power and normative aspects of the relationship. The existing literature mostly perceived onedirectional dynamics within which China's policies and activities exercise influence on 
CEE countries' perceptions of and approach to China. Implied in such a proposition is not only a lack of a feedback loop which would provide corrective to China's policymaking toward the region but, more fundamentally, a lack of agency on behalf of CEE countries and actors. Yet, CEE governments have proved not only adept at instrumentalizing China for their own domestic purposes and in the context of intraEuropean relations, but various actors have also played active roles in contributing to the ideational and material outcomes of the relationship with China in ways that have gone unaddressed in the existing literature.

Finally, the power relations within the triangular relationship between CEE, China, and the EU, while filling the pages of media and think tank reports, have mostly escaped a systematic scholarly investigation. Yet, as China's growing influence is taken for granted, and has caused not only rhetorical but also policy backlash from Brussels, there are few other as important questions to answer as what are the consequences of China's emergence as a regional actor for the EU, its relationship with $\mathrm{CEE}$, and their triangular relationships with China.

This special issue aims to address this research gap. The six contributions approach the China-CEE relations through diverse but complementary perspectives, including taking region, sub-regions, and individual states as units of analysis; exploring not only China's but also CEE countries' objectives, policy, and discursive strategies and diplomatic practices within their relationship; and placing their analysis in comparative frameworks, intra-regional, as well as of China and other external actors in the region. The six studies are contextualized in relation to the suitable scholarship in relevant (sub)disciplines and research areas in international relations, international political economy, international political sociology, and China studies, seeking to contribute to the emerging literature on the topic by striking a balance between empirical and theoretical aspects of research.

\section{Contributions to the special issue}

To this end, the special issue proceeds as follows:

The first three articles in the issue provide a macro-perspective-they identify discursive strategies and practices, the role and implications of China's developmental state model, and the development of new identities within China-CEE relations. China's arrival in CEE represents a disruptive development, as China has brought new thinking and practice with regard to economic cooperation and development and has also inspired a number of discussions - including self-reflective ones - about the trajectory and role of CEE in global politics.

With China's relationship with CEE evolving in recent years, the concerns about its implications have been amplified, both within and outside the region. In such a context, the finding of Jakimow's article that China strategically emphasizes economics over norms, culture over politics, and sovereignty over supranational commitments as the foundation of the BRI is of particular importance to understand how China has managed to engage CEE countries in and keep momentum behind 16+1 and BRI. The study finds that such discursive strategy has succeeded at engaging various actors in CEE in co-producing such a desecuritized discourse. Moreover, Jakimow argues that desecuritized narratives not only facilitate development of CEE-China ties but also are further instrumentalized by CEE countries with a political aim of negotiating their 
domestic interests with the EU's institutions, and China as an economic, political, and normative alternative to the EU.

In his article, Song argues that China's cooperation with the CEE countries represents a natural outgrowth of its state developmental model and Beijing's pursuit of an international leadership role. In practice, China has shaped its new relations with the CEE region following the logic of trial and error that has shaped China's own developmental experience. The outcomes of the China-CEE relationship are a mixed bag of successes and challenges. Yet, China's engagement with CEE has stirred tensions between its own, now globalizing developmental model, and the Western liberal blueprints. Song suggests that both China and CEE, not only in itself but also as a proxy to the wider international community, are still not as familiar and comfortable with each other and capable of facilitating relationship-building free of turbulences and skepticism, and that outcomes of relationship-building will depend on whether China and CEE countries can adapt to and accommodate each other.

Kavalski further examines the normative dimensions of China-CEE relationship. Yet, rather than dwelling on the normative impact of China on CEE, he identifies how developing a relationship with China has provided fertile ground for CEE countries and governments to construct and articulate their preferred identity as much domestically as in the wider context of European politics and international relations. Kavalski identifies how various actors in CEE intrumentalize China to emphasize their belonging to the EU, their independence from it, or its distinctive European identity respectively. Yet, it is precisely this growing significance that a relationship with China has for CEE countries that bears heavily on the prospects of the relationship. Beijing not only finds itself unwillingly playing a part in European identity politics, but is also confronted with a growing expectations-capability gap: does it have what it takes to remain relevant for CEE as expectations are growing, especially as these expectations are neither uniform nor complementary? As such, Kavalski's study also underlines how China-CEE relations result in unexpected and unintended outcomes that provide a shifting and challenging context for the involved parties, not least China, to navigate.

The three articles in the second part of this special issue adapt a case-study approach. Vangeli's article offers an insight into the mechanics and implications of the exchange and cooperation of Chinese and CEE think tanks. The work of Chinese think tanks is closely intertwined with the work of the government, and they have a particular role in the process of internationalization of the Chinese state. CEE think tanks on the other hand have been agents in the process of advancing the (neo)liberal agenda in the region in the aftermath of the Cold War. Coming from such different backgrounds, the interactions between Chinese and CEE think tanks have been rapidly increasing in recent years, not least through China-led channels for interaction such as the $16+1$ Think Tank Network. Based on participant observation of think tanks cooperation and exchanges, Vangeli's study finds that the dynamics of exchange between Chinese and CEE think tanks have been facilitating the process of ideational diffusion. Rooting his analysis in the reflexive social science, Vangeli identifies frames that are being established as Chinese actors manifest their symbolic power; geoeconomic imaginaries that are being extended by invoking the visions of the New Silk Roads; and policy concepts that are being translated through co-production of knowledge.

Garlick zooms in on the controversial case of CEFC - a Chinese private company that has made significant investments in the Czech Republic. CEFC attracted 
international attention, not least due to the growing portfolio of acquisitions around the world in strategically important sectors and contexts, and the questions over its relationship with Chinese state and its perceived political significance and influence implied therein. However, while CEFC in the Czech Republic was increasingly associated with the official position and actions of the Chinese state, the company collapsed as its finances unraveled, and its founder was detained in China. Garlick argues that the case of CEFC shows interplay of economic and political factors at work within China's economic diplomacy, and propensity of Beijing to use economic carrots in its diplomacy toward CEE to reap political benefits. Yet, this study also finds out that there is more fragmentation among Chinese actors than assumed in the scholarship on China's economic relationship with CEE. Employing the "principal-agent" framework, Garlick argues that Beijing failed to successfully coordinate and supervise the actions of CEFC, implying that behavior of various Chinese actors present in CEE is driven by diverging interests and rationalities rather than a single, coherent strategic vision and strategy.

In the article concluding this special issue, Pavlićević examines the competitive dynamics between China and the EU in the region by focusing on Western Balkans. The Western Balkan countries are perceived as more prone to China's influence, and more likely to diverge from the EU in seeking to build deeper political and economic ties with China. Repeatedly regarded as China's "Trojan Horse" in Anglophone media and by the EU officials, the Western Balkan countries are taken as prime example of how China's engagement of CEE does or may weaken EU's dominant role and influence across Europe. The article challenges such perceptions by examining and comparing China's and the EU's structural power in the Western Balkans, that is, their ability to shape and guide choices of Western Balkan countries through establishment of institutional, normative, and policy frameworks. While China's structural power has been indisputably growing since the establishment of $16+1$, the EU has since consolidated its leadership in the region through its own "structural diplomacy," ordering and limiting the space for China and the Western Balkans to independently develop their relationship.

In sum, this collection of studies contributes to the literature on China-CEE relations by providing novel and diverse perspectives on $16+1$ informed both by the particular local perspectives (Chinese and European) as well as situated within the international debates about modalities and implications of China's growing international presence and evolving foreign policy. It is our hope that this special issue contribute towards filling a major research gap by shedding light on some of the so-far hidden layers, unaddressed aspects, and unappreciated complexities of this relationship.

\section{References}

Fürst R, Tesar̆ F (2013) China's comeback in former Eastern Europe: no longer comrades, not yet strategic partners. Institute of Interantional Relations, Praha

Grgić M (2017) Chinese infrastructural investments in the Balkans: political implications of the highway project in Montenegro. Territ Polit Gov 7:1-19. https://doi.org/10.1080/21622671.2017.1359106

Grzywacz A (2019) Closer to a threat than an opportunity: Polish perception of China's rise and international engagement. Asia Eur J. https://doi.org/10.1007/s10308-019-00541-7 
Jakóbowski J (2018) Chinese-led regional multilateralism in Central and Eastern Europe, Africa and Latin America: 16 + 1, FOCAC, and CCF. J Contemp China 27:659-673. https://doi.org/10.1080 $/ 10670564.2018 .1458055$

Kamiński T (2019) What are the factors behind the successful EU-China cooperation on the subnational level? Case study of the Lodzkie region in Poland. Asia Eur J 17:227-242. https://doi.org/10.1007/s10308-018-00532-0

Kavalski E (2018) China's Belt and Road Initiative in Central and Eastern Europe. Asian Int Stud Rev 19(2): $13-32$

Kowalski B (2017) China's foreign policy towards Central and Eastern Europe: the "16+1" format in the South-South cooperation perspective. Cases of the Czech Republic and Hungary. Camb J Eurasian Stud 1:7R65ZH. https://doi.org/10.22261/7R65ZH

Matura T (2018) The Belt and Road Initiative depicted in Hungary and Slovakia. J Contemp East Asia Stud 7: 174-189. https://doi.org/10.1080/24761028.2018.1537091

Matura T (2019) China-CEE trade, investment and politics. Eur-Asia Stud 71:388-407. https://doi.org/10.1080/09668136.2019.1571166

McCaleb A, Szunomár Á (2017) Chinese foreign direct investment in Central and Eastern Europe

Pavlićević D (2018) 'China threat' and 'China opportunity': politics of dreams and fears in China-Central and Eastern European relations. J Contemp China 0:1-15. https://doi.org/10.1080/10670564.2018.1458057

Pavlićević D (2019) A power shift underway in Europe? China's relationship with Central and Eastern Europe under the Belt and Road Initiative. In: Li X (ed) Mapping China's "One Belt One Road" Initiative. Palgrave

Pendrakowska P (2018) Poland's perspective on the Belt and Road Initiative. J Contemp East Asia Stud 7: 190-206. https://doi.org/10.1080/24761028.2018.1552491

Pepermans A (2018) China's 16+1 and Belt and Road Initiative in Central and Eastern Europe: economic and political influence at a cheap price. J Contemp Cent East Eur 26:181-203. https://doi.org/10.1080/25739638.2018.1515862

Shang Y, Ponikvar N, Kejžar KZ (2016) The changing patterns of China-CEE trade. Eur-Asia Stud 68:14861505. https://doi.org/10.1080/09668136.2016.1244259

Song W (ed) (2017) China's relations with Central and Eastern Europe: from "old comrades" to new partners. Routledge

Song L \& Pavlićević D (2019) China's multilayered multilateralism: a case study of China and Central and Eastern Europe cooperation framework. Chin Polit Sci Rev 4: 277. https://doi.org/10.1007/s41111-019$00127-\mathrm{z}$

Tubilewicz C (1998) Comrades no more: Sino-Central European relations after the Cold War. Probl PostCommun 46:3-14

Turcsányi R, Qiaoan R (2019) Friends or foes? How diverging views of communist past undermine the ChinaCEE '16+1 platform'. Asia Eur J. https://doi.org/10.1007/s10308-019-00550-6

Vangeli A (2017) China's engagement with the sixteen countries of Central, East and Southeast Europe under the Belt and Road Initiative. China World Econ 25:101-124. https://doi.org/10.1111/cwe.12216

Vangeli A (2018) Global China and symbolic power: the case of 16+1 cooperation. J Contemp China 27:674687. https://doi.org/10.1080/10670564.2018.1458056

Wasserstrom J (2000) Chinese bridges to postsocialist Europe. In: Antohi S, Tismaneanu V (eds) Between past and future: the revolution of 1989 and their aftermath. Central European University Press, pp 357-382

Publisher's note Springer Nature remains neutral with regard to jurisdictional claims in published maps and institutional affiliations. 